\title{
WNK2 wt Allele
}

National Cancer Institute

\section{Source}

National Cancer Institute. WNK2 wt Allele. NCI Thesaurus. Code C143107.

Human WNK2 wild-type allele is located in the vicinity of 9q22.31 and is approximately $136 \mathrm{~kb}$ in length. This allele, which encodes serine/threonine-protein kinase WNK2 protein, is involved in serine/threonine phosphorylation of substrates that regulate electrolyte homeostasis and signal transduction. 